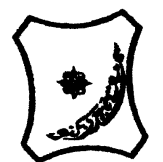

Bayero Journal of Pure and Applied Sciences, 8(2): 239 - 244

Received: June, 2015

Accepted: July, 2015

ISSN $2006-6996$

\title{
EXTRACTION AND PHYSICO CHEMICAL PROPERTIES OF SOME EDIBLE SEED OILS SAMPLED IN KANO METROPOLIS, KANO STATE.
}

\author{
Saeed, M.D. and Shola, E.A.
}

Department of Pure and Industrial Chemistry, Bayero University Kano, P.M.B 3011, Kano-Nigeria. dayyibmds@yahoo.com GSM: 08065026653

\section{ABSTRACT}

Six edible seed samples were obtained from Yankura market in Kano metropolis, Kano state. The samples were subjected to extraction for their oil contents. The percentage oil yield from the seeds were $40.60 \%$ for Moringa oleifera, $49.39 \%$ for cashew, $47.80 \%$ for sesame, $11.92 \%$ for bitter kola, $38.30 \%$ for melon and $\mathbf{2 8 . 6 8 \%}$ for water melon respectively. Proximate Analysis was also conducted and the results revealed that the moisture content of the seeds were in the range of $4.55 \%-9.51 \%$. The Ash contents ranged from $2.60 \%-4.50 \%$. The percentage crude fibre for these seeds ranged from 3.50\% - 12.00\%. The physicochemical properties of the oil extracts revealed that acid value contents were in the range of $0.0561 \mathrm{mgKOH} / \mathrm{g}-0.84 \mathrm{mgKOH} / \mathrm{g}$. Iodine value were in the range of $53.99_{\mathrm{g}} \mathrm{I}_{2} / 100_{\mathrm{g}}-124.4 \mathrm{~g}_{\mathrm{g}} / 0 \mathrm{O}_{\mathrm{g}}$. The peroxide values ranged from $3.45 \mathrm{meqKOH} / \mathrm{g}-13.41 \mathrm{meqKOH} / \mathrm{g}$ while the saponification values in the oil extracts were in the range of $162.42 \mathrm{mgKOH} / \mathrm{g}-$ $247.95 \mathrm{mgKOH} / \mathrm{g}$. The free fatty acids values ranged from $0.096 \mathrm{mgKOH} / \mathrm{g}-1.34 \mathrm{mgKOH} / \mathrm{g}$. The results of these analyses were subjected to one way analysis of variance (ANOVA) (p<0.05) and were all in agreement with standard values of AOAC, (1990) which implies that the oil extracted from these seed samples can be used for consumption and for industrial applications.

Keywords: Melon, Moringa, Oil yield, Physico chemical properties and Proximate composition.

\section{INTRODUCTION}

Oilseeds are leading suppliers of superior quality and specialty vegetable oils to nutritional products, natural food and premium snack food worldwide (Muhammad et al., 2013). Seed oils are important sources of nutritional oils, industrial raw materials and nutraceutical (Afolayan et al., 2014). Edible fats and oils are similar in molecular structure; however, fats are solid at room temperature, while, oils are liquid (Muhammad et al., 2013). Fats and oils are essential nutrients, comprising about $40 \%$ of the calories in the diet of the average person (Muhammad et al., 2013). Oil may be gotten from vegetables, animals or petrochemicals which may be volatile or non-volatile. Fat and oils are nutritionally important because they form one of the three major classes of food. Oils are used in a variety of ways, they are used for food texturing, baking, and frying and also are used industrially in the manufacture of soap, detergent, cosmetics and oil paints (Sarwal, 2013). In plants, oil is deposited in the seeds mostly in the endosperm along with carbohydrates where they jointly nourish the embryo (Oyeyiola, 1993). It is also found in some plants mesocarp e.g. in palm fruits. In animals, oil is found in various parts of the body e.g. liver (Oyeyiola, 1993). Oilseeds are also used in animal feed because of their high protein content (Muhammad et al., 2013). Their seeds contain energy for the sprouting embryo mainly as oil, compared with cereals, which contain the energy in the form of starch (McKevith, 2005). Many consumers are looking for variety in their diets and aware of the health benefits of fresh fruits and vegetables and of special interest are food sources rich in antioxidants (Aberoumand and Deokunle 2008).
Nutritional and industrial processes have increased the demands for oils and this in turn has led to the search for oils from different types of seeds. The aim of this work is to ascertain the oil content of these seeds and to see if they are economically viable.

\section{MATERIALS AND METHODS}

Sample collection

About $250 \mathrm{~g}$ of Moringa seed, cashew seed, sesame seed, bitter kola, melon, and water melon seed were randomly obtained from Yankura market in Kano city, Kano state Nigeria.

\section{Proximate Analysis}

Proximate composition of all seed samples were analyzed according to method described by AOAC (1990).

\section{Determination of Moisture Content}

Moisture was determined by oven drying method. Two grams of the sample was accurately weighed in clean, dried crucible $\left(\mathrm{W}_{1}\right)$. The crucible was allowed to dried in an oven at $100-105^{\circ} \mathrm{C}$ until a constant weight was obtained.Then the crucible was placed in the desiccator for $30 \mathrm{~min}$ to cool. After cooling it was weighed again $\left(W_{2}\right)$ The percent moisture was calculated using the formula below;

$$
\% \text { Moisture }=\frac{w_{1}-w_{2}}{\text { Weight of sample (Wo) }} \times 100
$$

Where:

W0 $=$ Weight of sample $(\mathrm{g})$

$\mathrm{W} 1$ = Initial weight of crucible + Sample $(\mathrm{g})$

W2 = Final weight of crucible + Sample $(g)$

AOAC, (1990) 
Bajopas Volume 8 Number 2 December, 2015 Determination of Ash Content

For the determination of ash, clean empty crucible was placed in a muffle furnace at $600^{\circ} \mathrm{C}$ for an hour, this was cooled in a desiccator, the weight of the empty crucible was recorded $\left(\mathrm{W}_{0}\right)$. Two grams of each of the samples was taken and placed in a crucible and this was recorded as $\left(W_{1}\right)$. Then the crucible was placed in muffle furnace at $550^{\circ} \mathrm{C}$ for 3 hours. The appearances of gray white ash indicated complete oxidation of all organic matter in the sample. After ashing, the furnace was switched off. The crucible was cooled and weighed $\left(\mathrm{W}_{2}\right)$. The percentage of the ash content was calculated using the formula below;

$\%$ Ash content $==\frac{w_{2}-w_{0}}{w_{1}-w_{0}} \times 100$

Where:

$\mathrm{W}_{0}=$ weight of empty crucible $(\mathrm{g})$

$\mathrm{W}_{1}=$ weight of crucible + powdered sample $(\mathrm{g})$

$\mathrm{W}_{2}=$ weight of crucible + ash sample $(\mathrm{g})$

AOAC, (1990)

\section{Determination of Crude Fiber}

Two grams of the sample was weighed $\left(w_{0}\right)$ into $1 \mathrm{dm}^{3}$ conical flask, $100 \mathrm{~cm}^{3}$ of water and $20 \mathrm{~cm}^{3}$ of $20 \% \mathrm{H}_{2} \mathrm{SO}_{4}$ were added and boiled gently for $30 \mathrm{mins}$. The content was filtered through whatman filter paper. The residue was scrapped back into flask with a spatula. One hundred $\mathrm{cm}^{3}$ of distilled water and $20 \mathrm{~cm}^{3}$ of (10\%) $\mathrm{NaOH}$ were added and this was allowed to boil gently for $30 \mathrm{mins}$. Th e content was filtered and the residue was washed thoroughly with hot water then rinsed once with $10 \% \mathrm{HCl}$ and twice with ethanol and finally three times with petroleum ether.

It was allowed to dry and then scrapped into the crucible and the content was allowed to dry overnight at $105^{\circ} \mathrm{C}$ in an oven. Later removed and cooled in a desiccator. The sample was weighed $\left(\mathrm{W}_{1}\right)$ and ashed at $550^{\circ} \mathrm{C}$ for $90 \mathrm{mins}$ in a letton muffle furnace. It was finally cooled in a desiccator and weighed again $\left(\mathrm{W}_{2}\right)$.

The percentage crude fibre was calculated using equation;

$\%$ crude fibre $=\frac{W_{1}-W_{2}}{w_{0}} \times \mathbf{1 0 0}$

Where:

$\mathrm{W}_{0}=$ weight of sample, $\mathrm{W}_{1}=$ weight of dried sample, $\mathrm{W}_{2}=$ weight of ash sample

AOAC, (1990)

\section{Extraction of oil}

The oil sample was extracted from the seeds of various samples by soxhlet extractor using petroleum ether with boiling point range $60-80^{\circ} \mathrm{C}$ for 8 hours.

The percentage of the oil yield in the samples analysed were obtained using the relation;

Oil yield $=\frac{W_{1}-W_{2}}{W_{1}} \times \mathbf{1 0 0} \%$

W1 = Weight of sample before extraction

W2 = Weight of sample after extraction

(Das et al., 2002)

\section{Determination of some physico chemical properties of oil}

\section{Determination of Acid Value}

Twenty five $\mathrm{cm}^{3}$ diethyl ether was mixed with $25 \mathrm{~cm}^{3}$ ethanol in a conical flask, $1 \mathrm{~cm}^{3}$ of $1 \%$ phenolphthalein indicator solution was added.

The mixture was neutralized with $0.1 \mathrm{M}$ potassium hydroxide solution then $1 \mathrm{~g}$ of the oil was added to the neutralized solvent mixture. This was then titrated with $0.1 \mathrm{M}$ potassium hydroxide solution. It was then shaken constantly until a pink colour which persists for 115 seconds was obtained.

Acid value $=\frac{(v b-V a) \mathrm{cm}^{2} \times \mathrm{5.61}}{\text { Wt of sampled uged }}(\mathrm{mgKOH} / \mathrm{g})$

$\mathrm{Va}=$ sample titre value,$\quad \mathrm{Vb}=$ blank titre value

(Ronald, 1991)

\section{Determination of Percentage Free Fatty Acids (FFA)}

One gram of the oil sample was accurately weighed into a conical flask. This was followed by the adding $10 \mathrm{~cm}^{3}$ of neutralized $95 \%$ ethanol and Phenolphthalein. This was then titrated with $0.1 \mathrm{M}$ $\mathrm{NaOH}$, with constant shaking until a pink colour persisted for 30s.

The percentage free fatty acid was calculated from Equation below:

Free Fatty Acid (FFA) $=\frac{V \times M \times 282 \mathrm{mg}}{\text { Sample weight }(\mathrm{g})}$ Where:

$\mathrm{V}=$ Volume of $\mathrm{NaOH}$

$\mathrm{M}=$ Molarity of $\mathrm{NaOH}$

2.82 = conversion factor of oleic acid AOAC, (1990)

Determination of Peroxide Value

One gram of the oil was weighed into a clean dry boiling tube, $1 \mathrm{~g}$ of powdered potassium iodide and $10 \mathrm{~cm}^{3}$ of the solvent mixture were added. The mixture was allowed to boil vigorously for 30 seconds. The tube was washed twice with $25 \mathrm{~cm}^{3}$ portions of water and the washings were added to the titration flask. This was then titrated with $0.002 \mathrm{M}$ Sodium thiosulphate using starch indicator.

The relation for peroxide value is given as;

Peroxide value $=$

$\frac{(\mathrm{Vb}-\mathrm{Va}) \mathrm{cm}^{\mathrm{E}} \times \text { molarity of titrant }}{\text { weight of oil }} \times 100(\mathrm{meqKOH} / \mathrm{g})$

Where:

$\mathrm{Va}=$ sample titre value $\quad \mathrm{Vb}=$ blank titre value

(Ranken, 1988)

\section{Determination of Saponification Value}

One gram of the oil was weighed into a flask. Twenty five $\mathrm{cm}^{3}$ of $0.1 \mathrm{M}$ alcoholic potassium hydroxide solution was added into the flask. A reflux condenser was attached and the flask was heated on a water bath for 1 hour with constant shaking. At the end of 1 hour the flask was removed from the water bath and $1 \mathrm{~cm}^{3}$ of the $1 \%$ phenolphthalein indicator was added. It was then titrated with the standard 0.5M hydrochloric acid. 


$$
\begin{aligned}
& \text { Saponification value } \\
& ==\frac{(\mathrm{V} b-\mathrm{Va}) \mathrm{em}^{2} \times 26.05}{\text { weigh of oil }}(\mathrm{mgKOH} / \mathrm{g}) \\
& \mathrm{AOAC},(1990)
\end{aligned}
$$

\section{Determination of Iodine Value}

Zero point two grams of the oil was weighed into a $250 \mathrm{~cm}^{3}$ glass stoppered flat, $10 \mathrm{~cm}^{3}$ of carbon tetrachloride was added to the oil and dissolved. Twenty $\mathrm{cm}^{3}$ Wijs' solution was equally added to the mixture and the content was corked with a stopper that initially moistened with potassium iodide solution. The mixture was titrated with 0.IM standard sodium thiosulphate solution using starch as an indicator just before the end point.

Iodine value $=\frac{(v b-v a) \mathrm{em}^{2} \times 1.269}{\text { weight of oil }(g)} \mathrm{gI}_{2} / 10$

AOAC, (1990)

\section{Statistical Analysis}

Data collected were subjected to one way analysis of variance (ANOVA) $(p<0.05)$ to assess whether they varied significantly between the seed samples. All statistical calculations were performed using SPSS software.

\section{RESULTS AND DISCUSSION}

From the table 1, the percentage oil yield for Moringa seed, cashew seed, sesame seed, bitter kola melon and water melon seed are $40.60 \%$, 49.34\%, $47.80 \% \%, 11.92 \%, 38.30 \%$ and $28.68 \%$ respectively. Most of these values were within the standard range $\mathbf{2 3 2} \%$ according to AOAC (1990). These amounts may be considered economical for commercial production of oil in Nigeria except for bitter kola that has low oil yield of $11.92 \%$.

Table 1: Results for percentage oil yield and proximate analysis in various seeds sample analysed.

\begin{tabular}{lllll}
\hline Sample & $\begin{array}{l}\text { Moisture } \\
\text { Content \% }\end{array}$ & $\begin{array}{l}\text { Ash } \\
\text { Content \% }\end{array}$ & $\begin{array}{l}\text { Crude fibre } \\
\text { \% }\end{array}$ & $\begin{array}{l}\text { \% oil } \\
\text { Yield }\end{array}$ \\
\hline Moringa Seed & $5.70 \pm 0.35$ & $3.93 \pm 0.09$ & $5.50 \pm 0.45$ & $40.60 \pm 0.29$ \\
Cashew Seed & $8.50 \pm 0.22$ & $2.60 \pm 0.08$ & $4.50 \pm 0.19$ & $49.34 \pm 0.51$ \\
Sesame Seed & $4.55 \pm 0.12$ & $4.02 \pm 0.26$ & $7.01 \pm 0.24$ & $47.80 \pm 0.61$ \\
Bitter kola Seed & $9.51 \pm 0.56$ & $4.50 \pm 0.78$ & $4.02 \pm 0.58$ & $11.92 \pm 0.07$ \\
Melon Seed & $5.23 \pm 0.42$ & $3.80 \pm 0.54$ & $12.00 \pm 0.53$ & $38.30 \pm 0.29$ \\
Water Melon & $4.78 \pm 0.33$ & $3.89 \pm 0.05$ & $3.50 \pm 0.23$ & $28.68 \pm 0.38$ \\
Seed & & & & $\geq 32$ \\
AOAC STANDARD, & & $2-5$ & $\leq 12$ & $\geq 32$ \\
$(1990)$ & $7-11$ & &
\end{tabular}

There is significant difference observed in the oil yield of the entire seed samples $(p<0.05)$. However, these results were in agreement with the result obtained by Ogbunugafor et al., (2011) who reported $41.47 \%$ oil yield for moringa seed, Yahaya et al., (2012) reported $44.00 \%$ oil yield for cashew seed, Warra, (2011) reported $48 \%$ oil yield for sesame seed. Therefore, only bitter kola oil is not considered as an oil seed for commercial purposes because of its low oil yield. But it may not be discouraged due to its high level of some parameters like saponification present in it which is used for soap making. Proximate analyses of the various seed samples were also analysed. The moisture content of moringa seed, cashew seed, sesame seed, bitter kola, melon, water melon were $5.50 \%, 8.50 \%$, $4.55 \%, 9.51 \%, 9.51 \%, 5.23 \%$ and $4.78 \%$ respectively. All these results were within the standard range $7-11 \%$ as reported by AOAC, (1990).

There is significant difference observed in the moisture content of the entire seed samples $(p<0.05)$. However, these results were in agreement with $5.7 \%$ moisture content as reported by Farooq and Bhanger (2003), also with $5.7 \%$ moisture content reported by Aremu et al., (2006). Nzikou et al., (2009) as well reported $5.70 \%$ moisture content for sesame seed. Taiwo et al., (2008) also reported $5.7 \%$ moisture content for water melon seed. The low moisture content for all these seed samples revealed that they can be preserved for a longer period (Taiwo, 2008).
The ash content of moringa seed, cashew seed, sesame seed, bitter kola, melon and water melon seed were $3.93 \%, 2.60 \%, 4.02 \%, 4.50 \%, 3.80 \%$ and $3.89 \%$ respectively. All these results fall within the standard range of $2-5 \%$ as reported by AOAC,(1990). There was no significant difference observed in the ash content of the entire seed samples $(p>0.05)$. However, all these results were in agreement with the results obtained by workers such as Farooq and Bhanger (2003) who reported 5.40\% for moringa seed.

Aremu et al., (2006) reported that cashew seed has ash content of $4.4 \%$, also with Nzikou et al., (2009) reported $3.7 \%$ ash content for sesame seed. Taiwo et al., (2008) also reported 3.88\% ash content for water melon seed. The results showed that the seed samples have significant amount of ash which are important sources of minerals (Taiwo, 2008).

Crude fibre above $12 \%$ indicates high level of undigested cellulose (Taiwo, 2008). Therefore, crude fibre of moringa seed, cashew seed, sesame seed, bitter kola, melon and water melon seed were $5.50 \%$, $4.50 \%, \quad 7.01 \%, \quad 4.02 \% \quad 12.00 \%$ and $3.50 \%$ respectively. All the results were $\leq \mathbf{1 2 a c c o r d i n g}$ to AOAC, (1990).which indicates that all the seed samples have low level of undigested cellulose. There is significant difference observed in the crude fibre content of the entire seed samples $(p<0.05)$. However, these results are in agreement with $6.60 \%$ crude fibre reported by Farooq and Bhanger (2003). 
Aremu et al., (2006) analysed his cashew sample and reported $1.2 \%$ for crude fibre content, also Nzikou et al., (2009) reported 3.2\% crude fibre for sesame seed. Taiwo et al., (2008) as well reported $6.10 \%$ crude fibre for water melon seed.

From table 2 below, oil fraction with saponification value of $\geq 180 \mathrm{mg} \mathbf{K O H} / \mathbf{g}$ had been reported to possess low molecular weight fatty acid AOAC,(1990). Therefore, oil gotten from moringa seed, sesame seed, biter kola, melon and water melon seed have saponification value of $182.89 \mathrm{mgKOH} / \mathrm{g}$, $192.70 \mathrm{mgKOH} / \mathrm{g}, 229.545 \mathrm{mgKOH} / \mathrm{g}, 247.95 \mathrm{mgKOH} / \mathrm{g}$, $192.09 \mathrm{mgKOH} / \mathrm{g}$, respectively.

Table 2: Physicochemical properties of the seeds sample analysed

\begin{tabular}{|c|c|c|c|c|c|c|}
\hline$\overline{\text { Sample }}$ & $\mathbf{P}^{\mathrm{H}}$ & $\begin{array}{l}\text { Acid } \\
\text { Value } \\
\text { mgKOH/g }\end{array}$ & $\begin{array}{l}\text { Free fatty } \\
\text { Acid } \\
\text { mgKOH/g }\end{array}$ & $\begin{array}{l}\text { Peroxide } \\
\text { value } \\
\text { meqKOH } / g \\
\end{array}$ & $\begin{array}{l}\text { Iodine } \\
\text { value } \\
\mathrm{gI}_{2} / 100 \mathrm{~g} \\
\end{array}$ & $\begin{array}{l}\text { Saponification } \\
\text { value } \\
\text { mgKOH/g }\end{array}$ \\
\hline $\begin{array}{l}\text { Moringa } \\
\text { Seed }\end{array}$ & 6.78 & $0.51 \pm 0.03$ & $0.23 \pm 0.01$ & $5.82 \pm 0.87$ & $68.00 \pm 0.01$ & $182.89 \pm 0.76$ \\
\hline $\begin{array}{l}\text { Cashew } \\
\text { Seed }\end{array}$ & 5.96 & $0.84 \pm 0.09$ & $1.34 \pm 0.34$ & $3.45 \pm 0.41$ & $48.45 \pm 0.43$ & $169.42 \pm 0.05$ \\
\hline $\begin{array}{l}\text { Sesame } \\
\text { Seed }\end{array}$ & 6.12 & $0.62 \pm 0.02$ & $0.28 \pm 0.02$ & $8.33 \pm 0.18$ & $116.05 \pm 0.54$ & $192.70 \pm 0.56$ \\
\hline $\begin{array}{l}\text { Bitter kola } \\
\text { Seed }\end{array}$ & 7.32 & $0.06 \pm 0.01$ & $0.096 \pm 0.01$ & $10.22 \pm 0.24$ & $53.99 \pm 0.34$ & $229.45 \pm 0.04$ \\
\hline $\begin{array}{l}\text { Melon } \\
\text { Seed } \\
\text { Water }\end{array}$ & 6.02 & $0.43 \pm 0.11$ & $0.24 \pm 0.05$ & $7.19 \pm 0.03$ & $124.40 \pm 0.67$ & $247.50 \pm 0.34$ \\
\hline $\begin{array}{l}\text { Melon } \\
\text { Seed }\end{array}$ & 6.42 & $0.51 \pm 0.04$ & $0.19 \pm 0.02$ & $13.41 \pm 0.43$ & $114.40 \pm 0.87$ & $192.09 \pm 0.07$ \\
\hline $\begin{array}{l}\text { AOAC } \\
\text { STANDARD, } \\
(1990)\end{array}$ & $5-7$ & $\leq 4.00$ & $\leq 1.30$ & $2-10$ & $80-100$ & $\geq 180$ \\
\hline
\end{tabular}

These values indicate that the oil has low molecular weight fatty acid which makes them useful in soap making. Whereas oil gotten from cashew seed has saponification value of $169.42 \mathrm{mgKOH} / \mathrm{g}$ which falls below the standard value $\geq 180 \mathrm{mgKOH} / \mathrm{g}$ according to AOAC, (1990). This implies that the oil cannot be used in soap making due to its high molecular weight of fatty acid. There is significant difference observed in the saponification value of the entire seed samples $(p<0.05)$.However these results are in agreement with the results obtained by other workers such as, Ogbungafor et al., (2011) who reported that saponification value for moringa seed as $171.90 \mathrm{mgKOH} / \mathrm{g}$. Idah et al,. (2014) also reported $161 \mathrm{mgKOH} / \mathrm{g}$ saponification value for cashew seed oil. Warra, (2011) reported $189 \mathrm{mgKOH} / \mathrm{g}$ saponification value for sesame seed oil. Egbebi, (2014) reported $190.4 \mathrm{mgKOH} / \mathrm{g}$ saponification value for melon seed oil. Acid value indicates whether the oil is in good nondegradable state or not. According to AOAC, (1990) the maximum acceptable level for acid value is $4 \mathrm{mgKOH} / \mathrm{g}$ oil. Below this value simply means that the oil is acceptable for consumption. Therefore, moringa seed, cashew seed, sesame seed, bitter kola, melon and water melon have acid values of $0.51 \mathrm{mgKOH} / \mathrm{g}$, $0.84 \mathrm{mgKOH} / \mathrm{g}, \quad 0.62 \mathrm{mgKOH} / \mathrm{g}, \quad 0.0561 \mathrm{mgKOH} / \mathrm{g}$, $0.43 \mathrm{mgKOH} / \mathrm{g}$, and $0.51 \mathrm{mgKOH} / \mathrm{g}$, respectively, which are within the standard range. Hence, these results show that the oils are in good non-degraded state which can be used for daily consumption. There is significant difference observed in acid value of the entire seed samples $(p<0.05)$. These results are in agreement with the results obtained by other workers such as, Farooq and Bhanger (2003) who reported that moringa seed oil has $0.40 \mathrm{mgKOH} / \mathrm{g}$ acid value. Warra, (2011) also reported $0.5 \mathrm{mgKOH} / \mathrm{g}$ acid value for sesame seed oil. Taiwo et al., (2008) reported $0.51 \mathrm{mgKOH} / \mathrm{g}$ acid value for water melon seed oil. However, the result of acid value for cashew seed oil is not in agreement with $1.94 \mathrm{mgKOH} / \mathrm{g}$ as reported by Idah et al., (2014).

Peroxide value of moringa seed, cashew seed, sesame seed and melon seed have a low peroxide value of $5.82 \mathrm{meqKOH} / \mathrm{g}, 3.45 \mathrm{megKOH} / \mathrm{g}, 8.33 \mathrm{meqKOH} / \mathrm{g}$ and $7.19 \mathrm{meqKOH} / \mathrm{g}$, respectively. All these values fall within the standard range of $2-10$ meqKOH $/ \mathrm{g}$ as reported by AOAC, (1990). This implies that the oils may be more stable to oxidative degradation, while bitter kola and water melon seeds have high peroxide values of $10.20 \mathrm{meqKOH} / \mathrm{g}$ and $13.41 \mathrm{meqKOH} / \mathrm{g}$, respectively. This implies that the oil is less stable to oxidative degradation.

There is significant difference observed in peroxide value of the entire seed samples $(p<0.05)$.However, the result of peroxide value for moringa seed oil was in agreement with $8.10 \mathrm{meqKOH} / \mathrm{g}$ reported by Ogbunugafor et al., (2011) and also with $8.00 \mathrm{meqKOH} / \mathrm{g}$ peroxide value for sesame seed oil reported by Warra et al., (2011). Whereas, the result of peroxide value for cashew seed oil is not in agreement with $44.4 \mathrm{meqKOH} / \mathrm{g}$ reported by Aremu et al., (2006), and also not in agreement with 
$12 \mathrm{meqKOH} / \mathrm{g}$ peroxide value for melon seed oil reported by Egbebi, (2014), but this is in agreement with $18.75 \mathrm{meqKOH} / \mathrm{g}$ peroxide value for water melon seed oil reported by Taiwo et al., (2008). Moringa seed, cashew seed, sesame seed, bitter kola, melon, and water melon seed have low free fatty acid content of $0.23 \mathrm{mgKOH} / \mathrm{g}, \quad 1.34 \mathrm{mgKOH} / \mathrm{g}, \quad 0.28 \mathrm{mgKOH} / \mathrm{g}$, $0.096 \mathrm{mgKOH} / \mathrm{g}, \quad 0.24 \mathrm{mgKOH} / \mathrm{g}$ and $0.19 \mathrm{mgKOH} / \mathrm{g}$ respectively. All these values fall below the standard limit value of $\leq 1.3 \mathrm{mgKOH} / \mathrm{g}$ as reported by $\mathrm{AOAC}$, (1990) except for cashew seed which exceeds the standard limit. Hence, oil with low free fatty acid value has lesser susceptible to rancidity according to ( $\mathrm{Li}$ et al., 2007). There was no significant difference observed in free fatty acid of the entire seed samples $(p>0.05)$ Iodine value is the measure of the properties of unsaturated organic compound (Pearson, 1981). It indicates the reactivity of double bond. Moringa seed, cashew seed, and bitter kola have low iodine value of $68.00 \mathrm{gI}_{2} / 100 \mathrm{~g}, 48.45 \mathrm{gI}_{2} / 100 \mathrm{~g}$ and $53.99 \mathrm{gI}_{2} / 100 \mathrm{~g}$ respectively which fall within the standard range of (80 - $100 \mathrm{gI}_{2} / 100 \mathrm{~g}$ ) as reported by AOAC,(1990). These oils have low degree of unsaturation and they are classified as the non-drying oil. Whereas, sesame seed, melon, and water melon seed have high iodine value of $116.05 \mathrm{gI}_{2} / 100 \mathrm{~g}, 124.40 \mathrm{gI}_{2} / 100 \mathrm{~g}$ and $114.4 \mathrm{gI}_{2} / 100 \mathrm{~g}$, respectively. This implies that the oil samples have high degree of unsaturation and they are classified as

\section{REFERENCES}

Aberoumand, A., and Deokule S. S. (2008): Determination of elements profile of some wild edible plants, Food Anal. Methods.doi: 10, 2008, 1007/s12161-0089038.

AOAC (Association Of Analytical Chemist): Official Method of Analysis 13th Ed. (1990). William Horwitz. Ed. Washington. DC, Association of Official Analytical Chemists,7: 56-132.

Aremu, M.O., Olonisakin, A., Bako D.A., and Madu P.C., (2006): Compositional Studies and Physicochemical Characteristics of Cashew Nut (Anarcadiumoccidentale) Flour. Pakistan Journal of Nutrition 5 (4): 328-333, 2006.

Atasie, V.N., Akinhanmi, T.F., and Ojiodu, C.C., (2009): Proximate Analysis and Physico- Chemical Properties of Groundnut (Arachishypogaeal.). Pakistan Journal of Nutrition, $\quad$ 8(2), 194197.

Das, M., Das, S.K., and Suthar, S.H (2002): Composition of seed and characteristics of oil from Karingda. International Journal of Food Science and Technology. 37:893 - 896.

Egbebi A.O (2014): Comparative studies on the three different species melon seed; (Citrulus vulgaries, Cucumeropsismanni and Leganariasiceraria). Sky Journal of Food Science Vol. 3(1), pp. 001 - 004, January, 2014.

Farooq, A., and M. I. Bhanger (2003): Analytical Characterization of Moringa oleifera Seed oil drying oil according to (Atasie et al., 2009). There is significant difference observed in iodine value of the entire seed samples $(p<0.05)$.

However these results are in agreements with the results obtained by other researchers such as, Ogbunugafor et al., (2011) who reported that moringa seed oil has $85 \mathrm{gI}_{2} / 100$ iodine value. Idah et al., (2014) also reported $86 \mathrm{gI}_{2} / 100 \mathrm{~g}$ iodine value for cashew seed oil. Warra, (2011) reported $103 \mathrm{gI}_{2} / 100 \mathrm{~g}$ iodine value for sesame seed oil. Egbebi, (2014) reported $114 \mathrm{gI}_{2} / 100 \mathrm{~g}$ iodine value for melon seed oil. The $\mathrm{pH}$ of moringa seed, cashew seed, sesame seed, bitter kola, melon and water melon seed were 6.67, $5.96,6.12,7.32,6.02$, and 6.42repectively. There is significant difference observed in the $\mathrm{pH}$ of the entire seed samples $(p<0.05)$.

\section{CONCLUSION}

The results of these studies is in agreement with standard result of AOAC, (1990), which implies that the oil obtained from moringa seed, cashew seed, sesame seed, melon and water melon seeds have high oil yield which can be considered economical for commercial production of oil in Nigeria, except bitter kola which has low oil yield. The chemical analysis also revealed that the seed samples were good for domestic consumption and industrial applications.

Grown in Temperate Regions of Pakistan. J. Agric. Food Chem. 2003, 51, 6558- 6563.

Li, S.G., H. Zhang and W.T. Xue, (2007): A novel method for the determination of acid value of vegetable oils. Eur. J. Lipid Sci. Tech., 109: 1088-1094.

McKevith B (2005). Nutritional aspects of oil seeds. Nutrition Bull. 30(1):3-26.

Idah, P. A., Simeon, M. I., and Mohammed, M. A., (2014): Extraction and Characterization of Cashew Nut (AnacardiumOccidentale) Oil and Cashew Shell Liquid Oil. Academic Research International Vol. 5(3) May 2014.

Muhammad,F.S., Muhammad, H.S., Muhammad, S., Niaz, A.Q., and Safia, M. (2013): The role of oilseeds nutrition in human health: $A$ criticalReview. Journal of Cereals and Oil seeds. Vol. 4(8), pp. 97-100

Nzikou, M.L., Matos, G., Bouanga-Kalou, C.B., Ndangui, N.P.G., Pambou T.A., Kimbonguila, M.L., and S. Desobry (2009): Chemical Composition on the Seeds and Oil of Sesame (Sesamum indicum L.) grown in Congo-Brazzaville. Advance Journal of Food Science and Technology 1(1): 6-11, 2009.

Ogbunugafor, H.A., .Eneh, F.U., Ozumba, A.N., IgwoEzikpe, M.N., Okpuzor, J., Igwilo, I.O., Adenekan, S.O., and Onyekwelu, O.A.,(2011): Physico-chemical and Antioxidant Properties of Moringa oleifera Seed Oil. Pakistan Journal of Nutrition 10 (5): 409-414, 2011. 
Oyeyiola, J.A. (1993): Nigerian Foods and Feeding Stuff IUP Ibadan: pp 50-52.

Pearson, D. A. (1981): Chemical Analysis of food (8th Edition). London: Church Hill Livingstone

Ranken, M. D. (1988): Food industries manual, $2^{\text {nd }}$ edition, published by AVI van Nostrand Reinhold company, New York.

Ronald, S. K. and Ronald, S. (1991): Composition and Analysis of foods. $9^{\text {th }}$ edition, Longman New York. Pp 507-544.

Sarwar, M. (2013): The theatrical usefulness of olive Oleaeuropaea L. (Oleaceae Family) nutrition in human health: A Review. Sky Journal of Medicinal Plant Research 2 (1): 14.

Taiwo, A.A., Agbotoba, M.O., Oyedepo, J.A., Shobo1, O.A., Oluwadare, I., and Olawunmi
M.O., (2008): Effects of drying methods on properties of water melon (citrullus lanatus) seed oil. African Journal of Food Agriculture, Nutrition and Development volume 8 No. (4) 2008.

Warra, A.A., Suraj, L.G. and Jega, S.A. (2011): Production of Soap from Northern Nigerian Sesame (Sesamumindicum, L.) Seed oil. Bayero Journal of Pure and Applied Science. 4(1):180-183

Yahaya A.T.1, Taiwo O., Shittu T.R., Yahaya L.E., Jayeola C.O. (2012): Investment in Cashew Kernel Oil Production Cost and Return Analysis of three Processing methods American Journal of Economics , 2(3): 4549. 